\title{
EKSPLORASI MOTIF BATIK PAKIDULAN GEOPARK CILETUH PALABUHANRATU
}

\author{
Nurul Anisa \\ Program Studi Pendidikan Matematika, Fakultas Keguruan dan Ilmu Pendidikan, Universitas Muhammadiyah \\ Sukabumi \\ nurulanisa005@ummi.ac.id
}

\begin{abstract}
Abstrak
Penelitian ini bertujuan untuk menggali unsur matematika pada batik pakidulan yang diharapkan dapat dijadikan sebagai media dalam pembelajaran matematika. Selain itu untuk mengetahui makna filosofis motif batik pakidulan serta macam-macam motif batik pakidulan untuk menambah wawasan siswa. Batik yang berasal dari geopark ciletuh palabuhanratu bernama batik pakidulan. Faktor yang mempengaruhi munculnya macam-macam motif batik pakidulan terinspirasi dari pesona alam, filososfi kehidupan masyarakat pakidulan, serta keanekaragaman budaya di Geopark Ciletuh palabuhanratu yang terlihat dari motif dan namanya. Batik pakidulan memiliki beberapa motif yang menjadi unggulan yaitu motif curug, motif panenjoan dan motif hujangan. Metode yang digunakan dalam penelitian ini adalah studi pustaka. Pada motif batik pakidulan terdapat konsep geometri seperti geometri datar dan transformasi. Geometri datar seperti segitiga sama kaki, jajargenjang dan belah ketupat terdapat pada motif rereng cimarinjung dan motif mata geulis. Konsep transformasi seperti refleksi, translasi dan rotasi terdapat pada motif penyu pauntuy-untuy serta motif suku ratu. Dengan demikian konsep geometri dapat digunakan sebagai pembelajaran matematika pada materi geometri.
\end{abstract}

Kata Kunci: Etnomatematika, Batik Pakidulan, Matematika, Geometri.

\section{PENDAHULUAN}

Mempelajari matematika di sekolah bukan saja membekali siswa sebagai upaya untuk persiapan siswa dalam menghadapi ujian sekolah dan ujian nasional, akan tetapi lebih dari itu tujuan dipelajarinya matematika di sekolah yaitu untuk mempersiapkan siswa agar dapat menggunakan matematika serta pola pikir matematik dalam kehidupan sehari-hari. Matematika adalah pengetahuan yang merupakan produk dari sosial budaya yang digunakan sebagai alat pikir dalam memecahkan masalah dan didalmnya memuat sejumlah aksioma-aksioma, definisi-definisi, teorema-teorema, pembuktian-pembuktian, masalah-masalah dan solusi-solusi. Yang menjembatani matematika dengan budaya disebut dengan istilah Etnomatematika (Aini et al., 2018; Rohmaini et al., 2020).

Menurut D'Ambrosio etnomatematika merupakan matematika yang dipraktikkan oleh kelompok budaya seperti masyarakat perkotaan dan pedesaan, kelompok buruh, anak-anak dari kelompok usia tertentu, masyarakat adat, dan lainnya . Adanya etnomatematika seringkali tidak disadari oleh masyarakat penggunanya.

Kesenian, rumah adat, pakaian tradisional, ukiran-ukiran, batik serta masih banyak lagi merupakan keberagaman budaya yang dimiliki Indonesia. Sehingga, tidak dapat dipungkiri apabila konsep matematika dapat ditemukan dalam keberagaman kesenian yang ada di Indonesia.

Batik berasal dari bahasa Jawa yaitu kata "amba" dan "tik" yang artinya adalah menulis titik (pada zaman dulu disebut ambatik). Maka batik adalah kain yang berlukiskan motif yang dibuat dengan cara menahan warna dengan lilin malam. Batik merupakan sebuah kesenian yang sarat akan makna. Batik bukan sekedar corak yang digambar oleh seniman batik. Melainkan tersirat sebuah pesan yang tersembunyi dalm motif atau gambar.

Corak dan jenis batik tradisional yang ada di Indonesia tergolong banyak, namun corak dan variasinya sesuai dengan filosofi dan budaya daerah batik itu berasal. Warisan budaya Indonesia yang beragam telah mendorong lahirnya berbagai corak dan jenis batik tradisional dengan ciri kekhususannya tersendiri. Pekalongan adalah salah satu daerah yang terkenal dengan batik khasnya. Namun ternyata Geopark Ciletuh-Palabuhanratu juga mempunyai batik.

Batik yang berasal dari geopark ciletuh palabuhanratu bernama batik pakidulan. Faktor yang mempengaruhi munculnya macam-macam motif batik pakidulan terinspirasi dari pesona alam, kehidupan masyarakat pakidulan, serta keanekaragaman budaya di geopark ciletuh palabuhanratu yang terlihat dari motif dan namanya. Batik pakidulan memiliki beberapa motif yang 
menjadi unggulan yaitu motif curug, motif panenjoan dan motif hujangan.

Selain ketiga motif diatas terdapat beberapa motif lain pada batik pakidulan diantaranya adalah sebagai berikut :

1. Motif Cimarinjung filosofi motifnya terinspirasi dari salah satu air terjun yang terdapat di kawasan geopark ciletuh palabuhanratu yang bernama curug cimarinjung.

2. Motif Pulau keris filosofi motifnya yaitu terinspirasi dari suatu pulau yang menyerupai keris tempat tersebut terdapat di kawasan geopark ciletuh palabuhanratu.

3. Motif Centreng filosofi motifnya terinspirasi dari tempat yang bernama panenjoan yaitu suatu tebing yang saat ini dijadikan tempat wisata karena keindahan alamnya.

4. Motif Emped filosofi motifnya terinpirasi dari suatu kepiting yang berganti kulit.

5. Motif Kima filosofi motifnya terinspirasi dari sebuah kerang laut.

6. Motif Soang Geboy filosofi motifnya terinspirasi dari bebek yang berjalan lunggaklenggok.

7. Motif Manuk Sukabungah filosofi motifnya terinspirasi dari burung pipit yang sering terlihat ketika panen padi.

8. Motif Mutiara Laut filosofi motifnya terinspirasi dari mutiara.

9. Motif Kupu-kupu filosofi motifnya terinspirasi dari kupu-kupu yang memiliki berbagai corak serta warna.

10. Motif Mata Geulis filosofi motifnya terinspirasi dari pemandang alam geopark ciletuh palabuhanratu.

11. Motif Keni filosofi motifnya terinspirasi dari sebuah kendi.

12. Motif Kipas filosofi motifnya terinspirasi dari kipas yang sering dipakai untuk menyejukan badan ketika kepanasan.

13. Motif Tegal Sabuk filosofi motifnya terinspirasi dari suatu tempat bersejarah yang ada dikawasan geopark ciletuh palabuhanratu.

14. Motif Penyu Midang filosofi motifnya terinspirasi penyu yang bertelur ditempat penangkarannya yang bernama midang.

Berikut ini beberapa contoh batik yang telah disebutkan diatas :

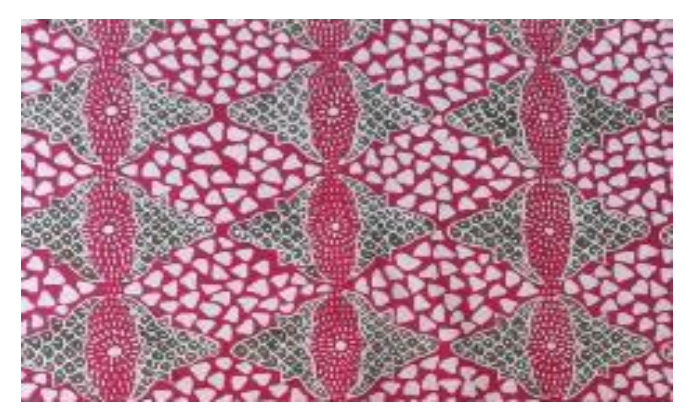

Gambar 1. Motif Tegal Sabuk

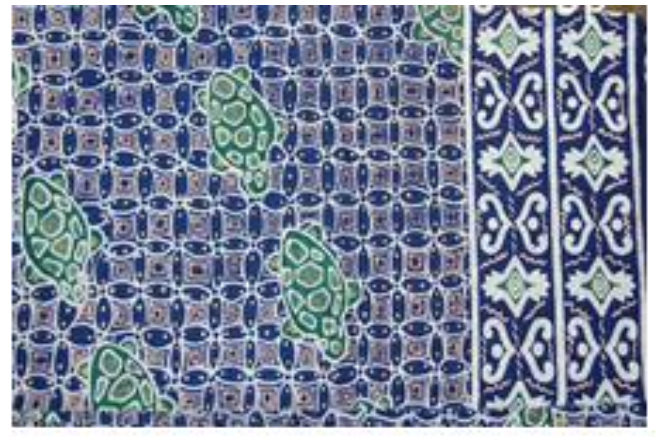

Gambar 2. Motif Penyu Pauntuy

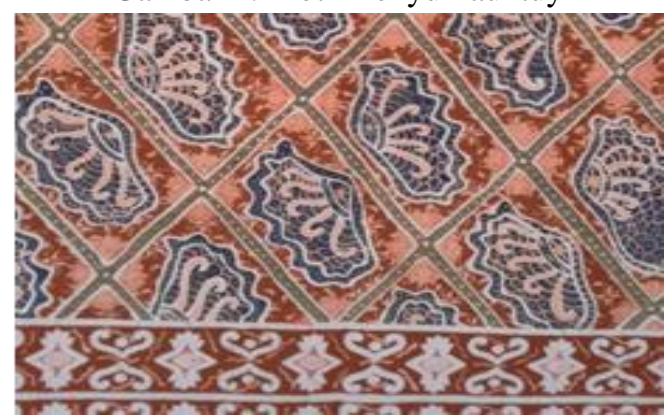

Gambar 3. Motif Kima

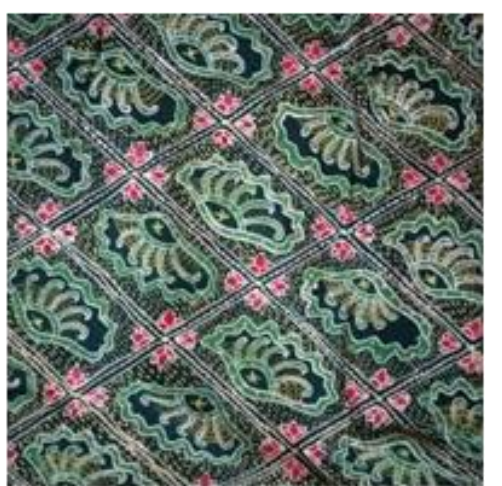

Gambar 4. Motif Mata geulis 


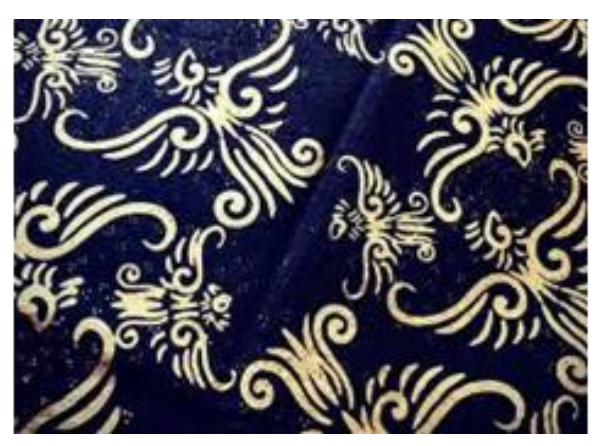

Gambar 5. Motif Manuk Ngupuk
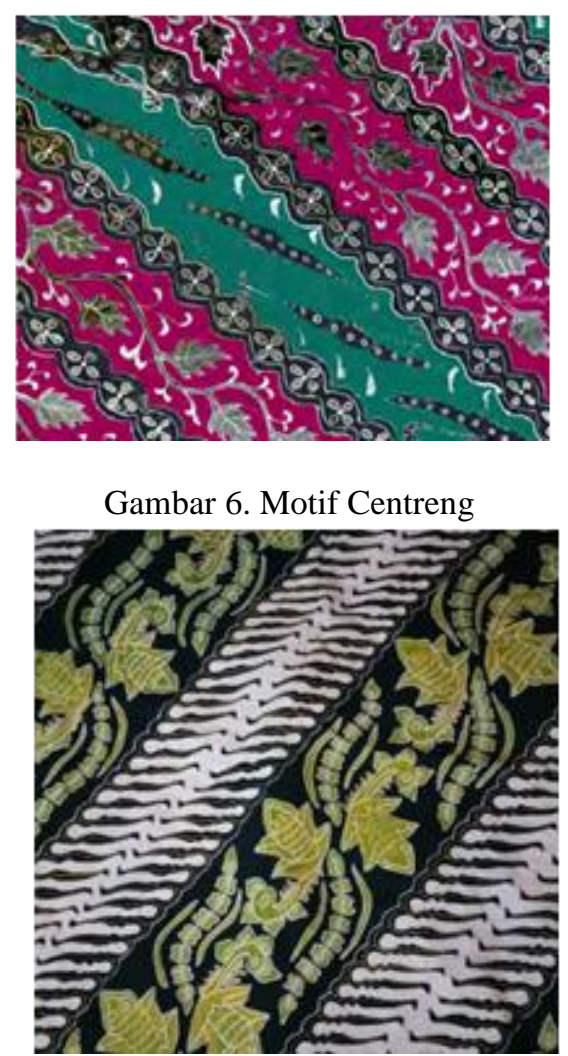

Gambar 7. Motif Suku Ratu

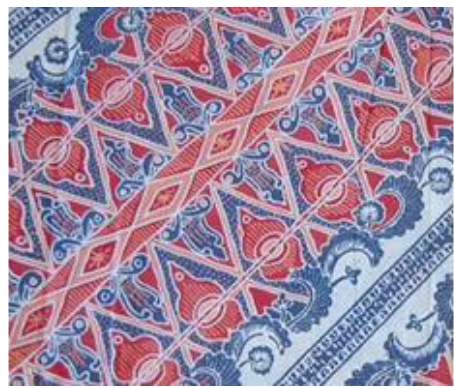

Gambar 8. Motif rereng Cimarinjung
Adanya penelitian ini bertujuan untuk menggali unsur matematika pada batik pakidulan yang diharapkan dapat dijadikan sebagai media dalam pembelajaran matematika. Selain itu untuk mengetahui makna filosofis yang terkandung dalam motif batik pakidulan serta macam-macam motif batik pakidulan untuk menambah wawasan siswa.

\section{METODE}

Metode penelitian yang digunakan dalam penelitian ini adalah metode studi pustaka. Metode studi pustaka menurut M.Nazir dalam bukunya yang berjudul "Metode Penelitian" mengemukakan bahwa yang dimaksud dengan study kepustakaan adalah teknik pengumpulan data dengan mengadakan studi penelaahan terhadap buku-buku, literatur-literatur, catatan-catatan, dan laporanlaporan yang ada hubungannya dengan masalah yang dipecahkan. Studi pustaka disebut pula degan istilah studi kepustakaan atau riset pustaka yang objek penelitiannya dapat ditelusuri di berbagai hasil karya ilmiah di perpustakaan atau media lainnya.

\section{HASIL DAN PEMBAHASAN}

Hasil dari penelitian ini berupa gambaran mengenai adanya keterkaitan antara matematika dengan keberagaman kesenian budaya Indonesia khusunya pada motif batik pakidulan geopark ciletuh palabuhanratu. Berdasarkan hasil analisis terdapat beberapa konsep matematika pada batik pakidulan. Konsep-konsep matematika tersebut antara lain konsep bangun datar dan konsep tranformasi. Konsep bangun datar yang ditemukan pada motif batik pakidulan diantaranya segitiga sama kaki, jajargenjang, dan belah ketupat. Bentuk artistik pada Batik Pakidulan dihasilkan melalui transformasi titik, garis, atau bidang datar melalui refleksi (pencerminan), translasi (pergeseran), dan rotasi (perputaran).

1) Bentuk Bangun Datar Pada Batik Pakidulan

Kosep bangun datar yang ditemukan pada motif batik pakidulan adalah segitiga sama kaki, belah ketupat dan jajargenjang. Berikut ini merupakan pemodelan geometri dari beberapa bangun datar yang terdapat pada motif batik pakidulan.

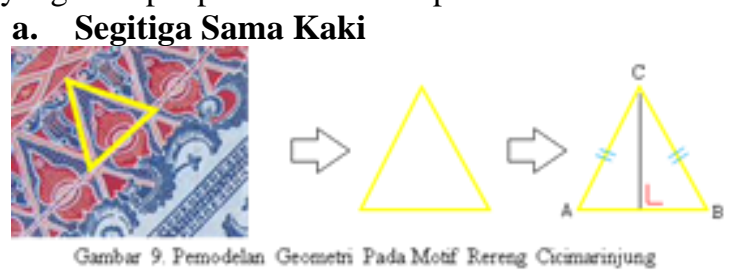

Motif rereng cimarinjung dapat dimodelkan secara geometri seperti pada gambar diatas. Berdasarkan pemodelan diatas terlihat sebuah bangun datar yang memenuhi syarat sebagai segitiga sama kaki. Sehingga dapat disimpulkan bahwa 
terdapat konsep segitiga sama kaki pada motif rereng cimarinjung.

Adapun sifat-sifat segitiga sama kaki yang dapat ditemukan pada permodelan motif rereng cimarinjunga adalah sebagai berikut :

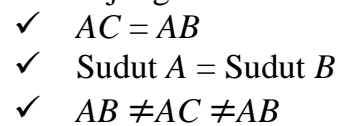

\section{b. Jajargenjang}

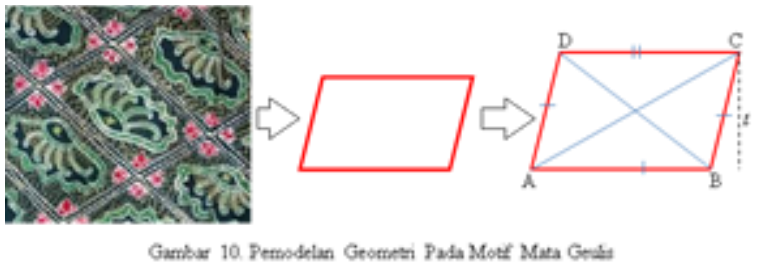

Berdasarkan hasil analisis pada gambar diatas diketahui bahwa pemodelan tersebut berbentuk bangun datar yang memiliki 4 sisi serta memenuhi syarat sebagai jajargenjang. Sehingga dapat disimpulkan bahwa terdapat konsep jajargenjang pada motif mata geulis.

Adapun sifat-sifat jajargenjang yang dapat ditemukan pada pemodelan motif mata geulis adalah sebagai berikut:

$\checkmark A D=B C$ dan $A B=D C$

$\checkmark$ Sudut $A=$ Sudut $C$ dan Sudut $D=$ Sudut $B$

$\checkmark$ Kedua diagonalnya saling membagi 2 sama panjang

$\checkmark$ Jumlah kedua sudut yang berdekatan adalah $180^{\circ}$ (sudut $A+$ sudut $B=$ sudut $C+$ sudut $D=$ $180^{\circ}$

\section{c. Belah Ketupat}

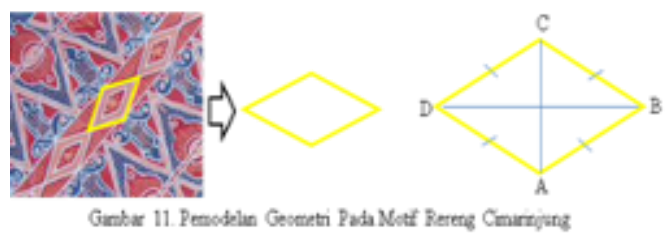

Berdasarkan hasil analisis pada gambar diatas diketahui bahwa pemodelan tersebut berbentuk bangun datar yang memiliki 4 sisi serta memenuhi syarat sebagai belah ketupat. Sehingga dapat disimpulkan bahwa terdapat konsep belah ketupat pada motif rereng cimarinjung.

Adapun sifat-sifat belah ketupat yang dapat ditemukan pada pemodelan motif rereng cimarinjung adalah sebagai berikut :

$\checkmark A B=B C=C D=D A$

$\checkmark \quad$ Sudut yang berhapadan sama besar $\checkmark$ Setiap diagonal membagi belah ketupat menjadi dua segitiga yang kongruen

$\checkmark$ Kedua diagonalnya saling berpotongan membentuk sudut siku-siku

Beberapa bentuk bangun datar yang terdapat pada motif batik pakidulan dapat digunakan untuk media pembelajaran di SMP kelas VII khususnya pada materi segi empat dan segitiga.

\section{2) Transformasi Pada Batik Pakidulan}

Selain terdapat konsep geometri datar pada batik pakidulan ternyata setelah dianalisis terdapat juga konsep lain pada motif batik pakidulan yaitu konsep transformasi. Adapun kajian mengenai konsepkonsep transformasi pada motif batik pakidulan dapat diuraikan sebagai berikut:

\section{a. Konsep Refleksi (Pencerminan)}

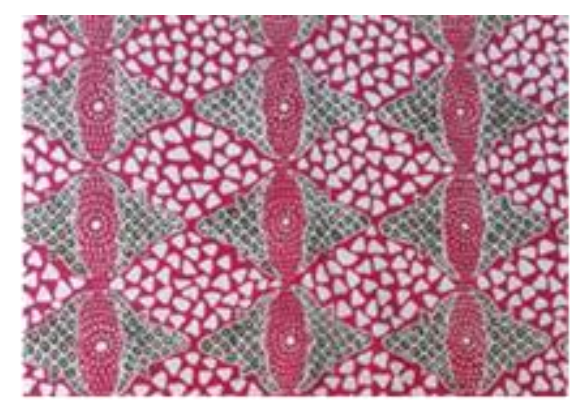

Gambar 12. Motif Tegal Sabuk

Bentuk dasar motifnya seperti sebuah segitiga pada gambar dibawah ini

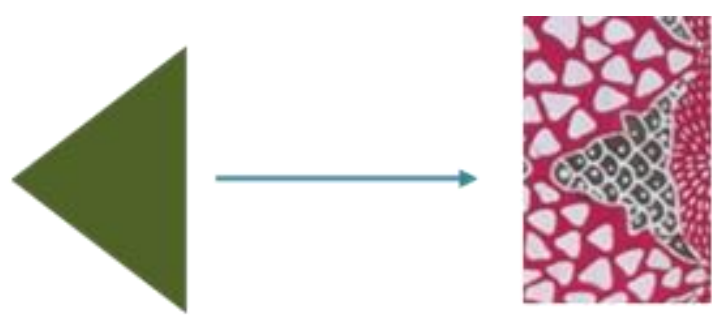

Gambar 13. Motif Dasar Sebelum Direfleksikan

> Sehingga diperoleh akan motif batik seperti pada gambar 12 .

Berdasarkan pemodelan diatas jenis refleksi pada motif tegal sabuk adalah jenis refleksi terhadap sumbu y. Dengan gambar pencerminan terhadap sumbu y adalah sebagai berikut :

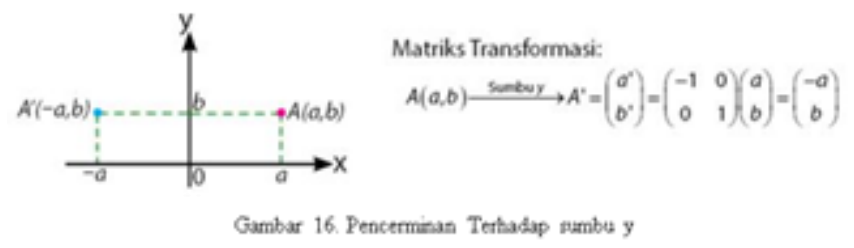

Sehingga dapat disimpulkan bahwa pada motif tegal sabuk terdapat konsep refleksi (pencerminan).

\section{b. Konsep Translasi (Pergeseran)}




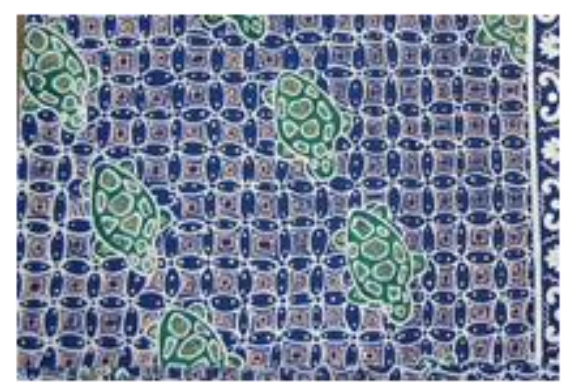

Gambar 16. Motif Penyu Pauntuy

Motif dasar yang ditranslasikan adalah motif penyu. Dengan menggeser motif dasar ke posisi tertentu searah kepala penyu, menggambarkan adanya konsep translasi dalam pembuatan motif batik pakidulan. Berikut ini contoh permodelan konsep translasi pada motif penyu pauntuy-untuy.

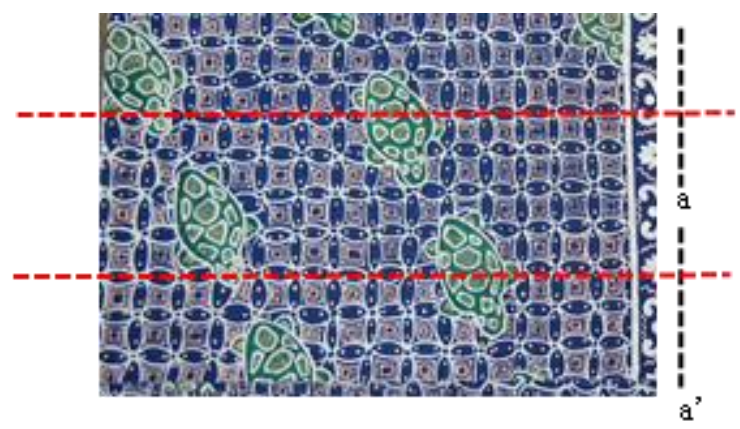

Gambar 17. Pemodelan Konsen Translasi

Pada gambar diatas motif penyu a digeser sekian satuan searah kepala penyu tanpa merubah ukurannya diperoleh motif penyu a', kemudian digeser sekian satuan searah kepala penyu sehingga diperoleh a", seterusnya sampai diperoleh motif penyu pauntuy untuy seperti gambar 16. Gambar translasi (pergeseran) adalah sebagai berikut.

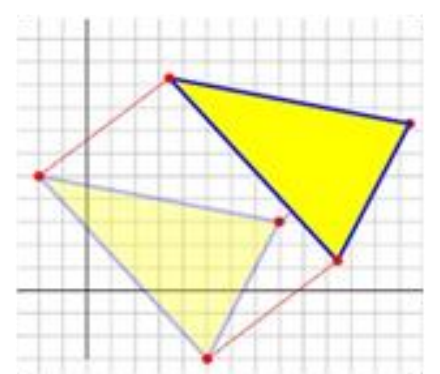

Gambar 18. Translasi (Pergeseran)

Sehingga dapat disimpulkan bahwa pada motif penyu pauntuy untuy terdapat konsep translasi (pergeseran).

c. Konsep Rotasi (Perputaran)

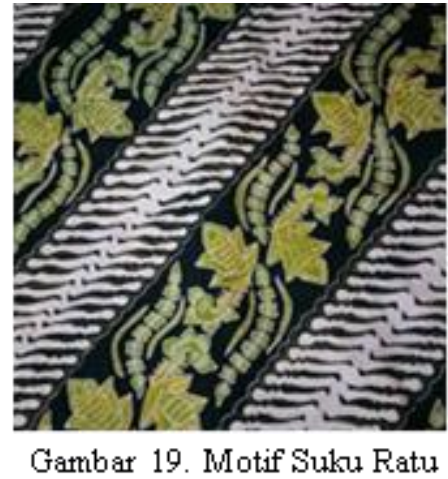

Motif dasar yang dirotasikan adalah motif yang menyerupai bunga. Konsep rotasi yang dimaksud didapat dengan cara memutar motif yang menyerupai bunga diputar sekian derajat searah jarum jam. Sebagai contoh permodelan seperti pada gambar dibawah ini :

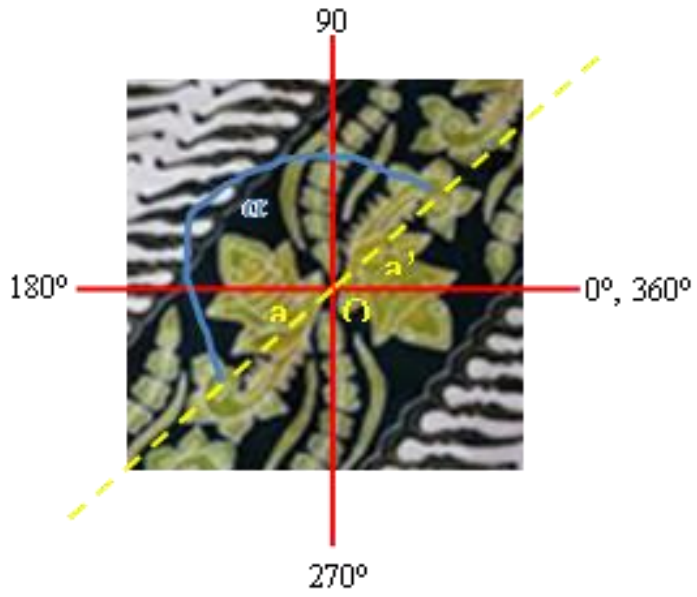

Gambar 20. Pemodelan Konsep Rotasi (Perputaran)

Gambar diatas menunjukkan bahwa motif penyu a dirotasikan sebesar $180^{\circ}$ searah jarum jam sehingga menghasilkan motif penyu a'. Rotasi tersebut berpusat di $\mathrm{O}(0,0)$ sebesar $180^{\circ}$. Maka diperoleh motif batik pada gambar 19. Gambar rotasi dengan pusat $\mathrm{O}(0,0)$ sebesar $180^{\circ}$ adalah sebagai berikut.

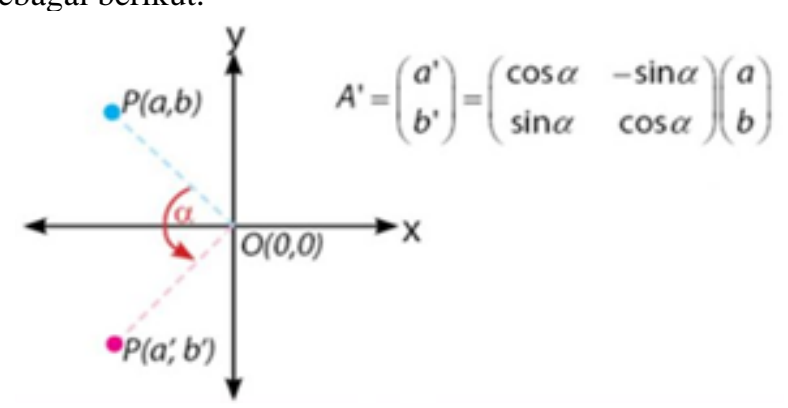

Gambar 21. Rotasi pusat $O(0,0)$ sebesar $\alpha$

Sehingga dapat disimpulkan bahwa pada motif suku ratu terdapat konsep rotasi (perputaran) yang berpusat di $\mathrm{O}(0,0)$ sebesar $\alpha$. 


\section{KESIMPULAN}

Dapat disimpulkan bahwa pada motif batik pakidulan terdapat konsep geometri seperti geometri datar dan transformasi. Geometri datar seperti segitiga sama kaki, jajargenjang dan belah ketupat terdapat pada motif rereng cimarinjung dan motif mata geulis. Konsep transformasi seperti refleksi, translasi dan rotasi terdapat pada motif penyu pauntuy-untuy serta motif suku ratu. Dengan demikian konsep geometri dapat digunakan sebagai media dalam pembelajaran geometri khususnya pada bab transformasi geometri.

Hasil dari penelitian ini diharapkan dapat menunjukan bahwa antara matematika dan budaya terdapat keterkaitan satu sama lain, sehingga proses pembelajaran matematika menjadi kontekstual, menarik dan mudah dipahami oleh siswa. Serta dapat menambah wawasan siswa mengenai batik pakidulan geopark ciletuh palabuhanratu.keberadaan matematika yang ada pada salah satu unsur budaya khususnya pada karya seni batik yang daerah mereka miliki.

\section{DAFTAR PUSTAKA}

Masaginews.com. (2018, 5 Juni). 10 Fakta Menarik Mengenai Batik Pakidulan Di Geopark Ciletuh. Diakses pada 13April 2020.

Flickr.com. (). Batik Pakidulan Sukabumi-Geopark Ciletuh. Diakses pada 6 April 2020.

Aini, E. P., Masykur, R., \& Komarudin, K. (2018). Handout Matematika berbantuan Etnomatematika Berbasis Budaya Lokal. Desimal: Jurnal Matematika, 1(1), 73-79. https://doi.org/10.24042/djm.v1i1.1950

Rohmaini, L., Netriwati, N., Komarudin, K., Nendra, F., \& Qiftiyah, M. (2020). Pengembangan Modul Pembelajaran Matematika Berbasis Etnomatematika Berbantuan Wingeom Berdasarkan Langkah Borg And Gall. Teorema: Teori Dan Riset Matematika, 5(2), 176-186.

Sudirman, Rosyadi, dan Lestari, Wiwit Damayanti. Penggunaan Etnomatematika Pada Karya Seni Batik Indramayu Dalam Pembelajaran Geometri Transformasi. Pedagogy. Volume 2, Nomor 1, ISSN 2502-3802.

Fikomnews.com. (2019). Indahnya Batik Pakidulan Sumber Kearifan Lokal Sukabumi Selatan. Diakses pada 6 April 2020.

Dudeja, Vid dan Madhavi, V. 2017. Jelajah Matematika Kelas SMP Kelas VII. Jakarta : Yudhistira.

Zed, Mestika. 2004. Metode Penelitian Kepustakaan. Jakarta : Yayasan Pustaka Obor Indonesia.

Darmayasa, Jero Budi, dan Hutauruk, J.B Agusmanto. 2018. Matematika Sekolah SMP. Yogyakarta : Deepublish.
Kurniawan, Hendra. 2018. Mosaik Afrika Kapita Selekta Afrika Dalam Sejarah. Sukabumi : CV Jejak. 